\title{
PEMBELAJARAN DENGAN MEDIA BERBASIS PROBLEM BASED LEARNING PADA MATERI TEKANAN DALAM MENGEMBANGKAN SIKAP PESERTA DIDIK
}

\author{
Dewi Rahmawati ${ }^{1}$, Desi Wulandari ${ }^{2}$ \\ Program Studi Tadris IPA Institut Agama Islam Negeri Jember, Jember, Indonesia \\ *Corresponding Author: dw2257167@gmail.com
}

DOI: $10.35719 /$ vektor.v2i1.14

\begin{abstract}
Abstrak. Dalam pembelajaran IPA untuk memenuhi ketentuan dalam kurikulum 2013 bahwasanya pembelajaran dilakukan dengan mengajarkan materi pada peserta didik untuk mengembangkan kompetensi yaitu kompetensi sikap spiritual, sosial, pengetahuan dan keterampilan. Untuk melaksanakan pembelajaran tersebut pembelajaran yang diterapkan yaitu mengajarkan materi tekanan hidrostatis. Pembelajaran IPA pada materi Tekanan dengan sub materi Tekanan Hidrostatis serta dalam penerapan sehari-harinya dilakukan dengan model Problem Based Learning. Model tersebut disajikan sebuah demonstrasi produk dari guru untuk mengamati percobaan yang didemonstrasikan. Sub materi yang disampaikan juga terkait materi Hukum Torricelli dengan penerapannya dalam kehidupan sehari-hari. Pembelajaran dengan materi tersebut diintegrasikan dalam ranah afektif yaitu spiritual dan sosial serta keterpaduan antara cabang ilmu lainnya. Kajian spiritual yang diberikan disajikan dalam mengaitkan atau mengintegrasikan dengan firman Allah SWT. QS. QS. Al-Ma'arij (70): 19-35 dan (QS. Asy-Syarh (94): 5-6). Dalam kajian sosial yaitu dapat dipadukan dengan kegiatan pemeliharaan kelestarian dan peduli lingkungan dalam firman Allah SWT. (QS An Nahl 16:10). Dalam memenuhi kompetensi dalam kurikulum 2013 pembelajaran, pembelajaran dalam ranah pengetahuan yang bersifat keterpaduan IPA yaitu kajian fisika dengan biologi tentang siklus hidrologi dapat dikaji dan dilakukan pembelajaran dengan menjelaskan kandungan ayat dalam firman Allah SWT. QS. An Nur : 43. Dengan menyertakan firman Allah SWT agar dapat diterapkan dalam kehidupan sehari-hari, baik dalam lingkungan keluarga maupun lingkungan sosial bermasyarakat.
\end{abstract}

Kata kunci: Afektif, Hukum Torriceli, Kurikulum 2013, PBL (Problem Based Learning), Tekanan

\begin{abstract}
In science learning to meet the provisions in the 2013 curriculum, learning is carried out by teaching material to students to develop competencies, namely the competence of spiritual, social, knowledge and skills attitudes. To carry out this learning, the thing applied is to teach hydrostatic pressure material. Science learning on Pressure material with submaterial Hydrostatic Pressure and in its daily application is carried out with the Problem Base Learning model. The model presented a product demonstration of the teacher to observe the experiment being demonstrated. The sub-material presented is also related to Torricelli's Law material and its application in everyday life. Learning with this material is integrated in the affective realm, namely spiritual and social as well as integration between other branches of science. The spiritual studies given are presented in linking or integrating with the word of Allah SWT. QS. QS. Al-Ma'arij (70): 19-35 and (Surah Asy-Syarh (94): 5-6). In social studies, it can be combined with activities to maintain sustainability and care for the environment in the word of Allah SWT. (Surah An Nahl 16:10). In fulfilling the competencies in the 2013 learning curriculum, learning in the realm of knowledge that is integrated in science, namely the study of physics with biology about the hidurology cycle, can be studied and carried out by explaining the content of the verse in the word of Allah SWT. QS. An Nur: 43. By including the word of Allah SWT. so that it can be applied in everyday life, both in the family environment and in the social environment
\end{abstract}

Keywords: Affective, Curriculum 2013, Torriceli Law, PBL (Problem Based Learning), Pressure 


\section{PENDAHULUAN}

Sains merupakan pengetahuan yang melingkupi suatu kebenaran dari hukumhukum alam yang terjalin dimana diperoleh dan dibuktikan melalui metode ilmiah. Dalam hal ini sains merujuk pada suatu sistem untuk memperoleh pengetahuan dengan menggunakan percobaan serta eksperimen untuk menggambarkan fenomena-fenomena yang terjalin di alam. Sains berkaitan dengan udara, tanah serta air. Dari ketiganya memiliki peranan masing-masing dalam kehidupan sehari hari, seperti halnya air pada materi dalam pembelajaran IPA yang menjelaskan tentang tekanan zat cair ataupun tekanan hidrostatis. Pembahasan fluida statis ini erat kaitannya dengan aktivitas kehidupan sehari-hari. Fluida statis membahas mengenai tekanan hidrostatis, hukum Pascal, dan hukum Archimedes (Al Mubarokah NH, 2019); (Serway RA, Jewett JW, 2018); (Knight RD, 2017); (Young HD, 2015) dalam [1]. Dimana pada hukum Pascal terdapat pengetahuan dasar mengenai tekanan hidrostatis. Tekanan hidrostatis adalah tekanan yang diakibatkan oleh gaya yang ada pada zat cair terhadap suatu luas bidang tekanan pada kedalaman tertentu (Serway RA, Jewett JW, 2018); (Knight RD, 2017) dalam [1]. Secara konseptual tekanan hidrostatis terjadi atas dasar hukum Pascal. Konsep penting yang perlu dipahami dalam materi fluida statis, khususnya tekanan hidrostatis ialah tekanan hidrostatis tidak dipengaruhi oleh massa jenis wadah, melainkan dipengaruhi oleh massa jenis zat cair, udara di sekeliling, percepatan gravitasi dan kedalaman dari benda yang berada di dalam zat cair tersebut, konsep penting yang perlu dipahami juga ialah prinsip-prinsip dari hukum Pascal (Al Mubarokah NH, 2019); (Zukhruf KD, Khaldun I, Ilyas S, 2016); (Serway RA, Jewett JW, 2018) dalam [1]. Pada materi tekanan hidrostatis, terkait dalam menguasai konsep bahwa di dalam zat cair, semakin ke bawah tekanannya semakin besar (Kanginan, 2008) dalam[2]. Tekanan yang semakin ke bawah semakin besar tidak terlihat sehingga perlu divisualisasikan. Salah satu bentuk visualisasi tersebut dapat dilakukan dengan melalui percobaan. Percobaan yang biasa dilakukan adalah dengan menuangkan air yang pada sebuah botol berlubang dengan posisi lubang yang bervariasi ketinggiannya. Proses belajar dan pembelajaran ini dapat menjadikan siswa berpikir secara mendalam dengan terlibat secara aktif pada serangkaian kegiatan sehingga pada akhirnya dapat mengkonstruksi pengetahuan dan informasi ke dalam struktur kognitif yang komprehensif (Arends, 2012:327) dalam(Rahmawati et al., 2016).

Dalam pembelajaran, khususnya pada tingkat menengah yaitu SMP/MTs, materi tekanan diajarkan pada kelas 8 menurut kurikulum 2013. Dalam pelaksanaan terkait kurikulum 2013 oleh Kemendikbud (2013) dalam [4] dimana pembelajaran yang dikembangkan pendidik yakni pembelajaran aktif yang berfokus pada keaktifan siswa dan guru sebagai fasilitator. Mengingat pentingnya peran pendidik dalam hal ini, untuk itu sangat diperlukan kemampuan dalam mengelola kegiatan pembelajaran. Upaya untuk dapat meningkatkan keberhasilan belajar siswa dapat dilakukan di antaranya melalui memperbaiki proses pembelajaran. Dalam memperbaiki proses pembelajaran ini peranan pendidik sangat peting, yaitu menetapkan model pembelajaran yang tepat sesuai dengan konsep ilmu yang akan disampaikan [4].

Dari uraian diatas melatarbelakangi penulis untuk mengkaji sebuah materi pembelajaran dengan menerapkan model pembelajaran yang sesuai dengan kebijakan kurikulum 2013 yaitu pembelajaran IPA materi Tekanan dengan menggunakan model pembelajaran PBL (Problem Based Learning). Problem atau masalah yang disajikan oleh tenaga pendidik yaitu dengan mendemonstrasikan kerja miniatur pancuran berdasarkan perbedaan ketinggian lubang pancuran sebagai objek pengamatan untuk peserta didik dalam pelasanaan pembelajaran. Pelaksanaan akan pembelajaran dengan model tersebut dapat dijalankan sesuai kompetensi yang terdapat dalam kurikulum 2013, dimana di 
dalamnya terdiri dari kompetensi inti untuk mengembangkan sikap spiritual religius, sosial, pengetahuan dan keaktifan peserta didik. Dalam kompetensi tersebut tersusun dalam satu materi dengan mengintegrasikan keempat nilai tersebut.

Oleh karena itu, dalam pembelajaran IPA pada materi Tekanan dapat dilakukan proses pembelajaran dengan menerapkan dan mengembangkan kompetensi berdasarkan kurikulum, yaitu memberikan pembelajaran dengan memenuhi tiga ranah yang diantaranya afektif, kognitif dan psikomotorik. Pembelajaran akan bermakna jika dikaitkan atau dihubungkan serta diintegrasikan dengan kehidupan sehari-hari. Pengintegrasian akan pembelajaran akan mengembangkan karakter peserta didik. Pengimplementasian kurikulum 2013 secara bertahap dilakukan oleh pemerintah dengan adanya penekanan aspek afektif dan sosial yang terdapat dalam kompetensi inti 1 dan kompetensi inti 2 yang wajib ada dalam seluruh mata pelajaran di sekolah di dalam kurikulum 2013 (Dekdikbud, 2013) dalam [5]. Diharapkan dengan kurikulum 2013 ini akan mampu menjawab tantangan global dan menjadi manusia yang berakhlak mulia, berilmu, kreatif, mandiri, dan menjadi warga negara yang demokratis serta bertanggung jawab sesuai tujuan Nasional Pendidikan. Menurut (Said, 2011) dalam [5] karakter artinya mempunyai kualitas positif seperti peduli, adil jujur hormat terhadap sesama, rela memaafkan, sadar akan hidup, berkomunitas dan sebagainya.

Dengan ini penulis melakukan kajian dengan mengembangkan Pembelajaran dengan Media Berbasis PBL pada Materi Tekanan dalam Mengembangkan Potensi dalam Ranah Sikap Peserta Didik. Hal ini dapat menjadi kajian yang berguna dalam penerapan pembelajaran yang berlaku dan sesuai dengan kurikulum 2013 yang bertujuan untuk: 1). Mendeskripsikan pembelajaran IPA pada materi Tekanan dengan model pembelajaran berbasis masalah yaitu salah satunya dengan menggunakan PBL (Problem Based Learning); 2). Mendeskripsikan pembelajaran IPA dengan model PBL berbantuan media miniatur pancuran melalui proses pengamatan; 3). Menerapkan pembelajaran IPA tersebut dengan mengintegrasikan nilai-nilai atau ranah sikap dalam kehidupan seharihari.

\section{METODE}

Penelitian ini adalah penelitian deskriptif dengan pendekatan kualitatif. Kajian yang dilakukan dengan mengumpulkan beberapa teori terkait materi Tekanan, model pembelajaran PBL (Problem Based Learning), Kurikulum 2013, Pendidikan Karakter, sikap Afektif dan kajian keislaman yang berhubungan dengan sikap afektif manusia. Kajian ini berisikan kajian pustaka yang menjadikan landasan bagi pendidik untuk mengembangkan kompetensi guru. Potensi guru yang dikembangkan dalam kajian ini dilakukan dengan mengembangkan produk atau media dalam pembelajaran materi tekanan dengan model problem based learning. Produk yang dikembangkan dilakukan dengan prosedur selayaknya percobaan atau kegiatan praktikum sebagai berikut. Alat dan bahan yang diperlukan terdiri: Penggaris, Paku, Korek api, Isolasi, Pipet tetes, Spidol warna, Botol bekas, Air, Pewarna makanan, Kertas. Untuk prosedur pembuatan: 1) Disiapkan alat dan bahannya terlebih dahulu; 2) Buatlah jarak pada botol antara titik satu dengan yang lain, dengan jarak $5 \mathrm{~cm}$ sebanyak 5 titik; 3) Dilubangi botol yang telah ditandai dengan paku dengan bantuan korek api agar lebih memudahkan; 4) Ditutup lubang tersebut menggunakan isolasi; 5) Diisi air botol tersebut; 6) Diteteskan pewarna makanan ke dalam air tersebut menggunakan pipet tetes; 7) Ditaruh botol yang berisi air tersebut di wadah yang telah disiapkan dan taruh juga penggaris dalam wadah tersebut agar memudahkan ketika mau mengukur jarak pancaran air; 8) Dilepaslah isolasi tersebut satu persatu dan jangan lupa diamati jarak pancaran airnya berapa; 9) Dicatat hasil yang telah didapat. 


\section{HASIL DAN PEMBAHASAN}

\section{Tekanan}

Konsep tekanan sangat penting dalam mempelajari sifat fluida. Besar tekanan didefinisikan sebagai gaya tiap satuan luas. Persamaan tekanan ditulis sebagai berikut:

$$
P=\frac{F}{A}
$$

Keterangan:

$P=\operatorname{Tekanan}\left(\mathrm{N} / \mathrm{m}^{2}\right)$

$F=\operatorname{Gaya}(N)$

$A=$ Lusa bidang tekan $\left(m^{2}\right)$

Satuan tekanan dalam SI adalah N/m2 atau disebut juga pascal, disingkat Pa.

Berdasarkan perumusan di atas diperoleh bahwa tekanan berbanding terbalik dengan luas bidang tekan. Itulah sebabnya penerapan konsep tekanan dalam kehidupan sehari-hari dapat kita jumpai seperti pisau, paku, dan pasak. Alat-alat tersebut perlu di buat runcing atau tajam untuk memperoleh tekanan yang besar [6].

Tekanan Hidrostatis

Bejana dengan luas penampangnya A berisi zat cair yang massa jenisnya $\rho$ setinggi h sebagaimana tampak pada Gambar 1 berikut.

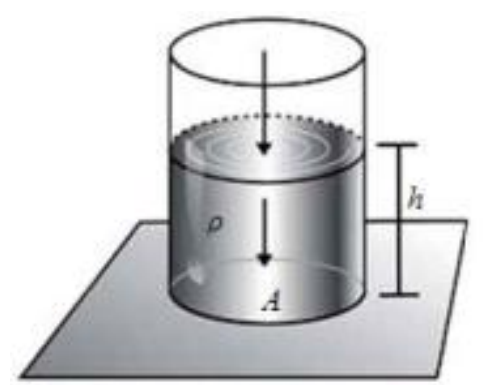

Gambar 1. Bejana dengan luas penampang A berisi zat cair setinggi $h$

Berat zat cair menekan alas bejana. Besarnya gaya tekan zat cair yang dialami oleh alas bejana tiap satuan luas disebut tekanan hidrostatis. Tekanan hidrostatis oleh zat cair dapat dituliskan persamaannya sebagai berikut.

$$
\begin{gathered}
P_{H}=\frac{W}{A}=\frac{m \times g}{A}=\frac{(\rho \times V) g}{A}=\frac{(\rho \times A \times h) g}{A} \\
P_{H}=\rho \times g \times h \ldots \ldots \ldots \ldots(2)
\end{gathered}
$$


Keterangan:

$P_{H}=$ Tekanan hidrostatis $(\mathrm{Pa})$

$\rho=$ Massa jenis fluida $\left(\mathrm{kg} / \mathrm{m}^{3}\right)$

$g=$ Percepatan gravitasi bumi $\left(\mathrm{m} / \mathrm{s}^{2}\right)$

$h=$ Kedalaman fluida $(m)$

Jika pada tekanan atmosfer di permukaan zat cair itu adalah tekanan total di tempat atau titik yang berada pada kedalaman $\mathrm{h}$ dapat ditulis sebagai berikut.

$$
P_{H}=P_{0}+\rho \times g \times h
$$

[6].

Oleh karena itu, tekanan hidrostatis dikenal atau disebut dengan istilah fluida statis, karena tekanan zat cair dalam keadaan statis dan hanya disebabkan oleh beratnya sendiri [7].

Terkait penerapan tekanan zat cair pada bejana yang ditunjukkan pada gambar 1 , Jika air di dalam wadah mengalami kebocoran, kelajuan air yang memancar keluar dari lubang tersebut dapat dihitung. Berdasarkan Hukum Toricelli, jika diameter lubang kebocoran pada dinding wadah sangat kecil dibandingkan diameter wadah, kelajuan air yang keluar dari lubang sama dengan kelajuan yang diperoleh jika air tersebut jatuh bebas dari ketinggian $\mathrm{h}$ [7]. Hukum Torricelli dapat diterapkan pada suatu galon yang diisi oleh air, pada bagian bawah terdapat keran untuk keluarnya air, laju perubahan volume air dibandingkan dengan ukuran tangki. Sebelum keran galon dibuka dan air keluar dari galon pada ketinggian tertentu, air memiliki energi potensial, dan saat air keluar dari keran, energi potensial berubah menjadi energi kinetik. Energi potensial pada ketinggian air adalah $\mathrm{mgh}$, dengan $\mathrm{g}$ adalah percepatan gravitasi bumi, $m$ adalah massa dan $\mathrm{h}$ adalah ketinggian. Misalkan kecepatan air yang keluar dari keran pada saat ketinggian air $\mathrm{h}$ adalah $\mathrm{v}(\mathrm{h})$, maka energi kinetik yang dihasilkan adalah

$$
\frac{1}{2} m v(h)^{2}
$$

(Groetsch, 2012) dalam [8]

Berdasarkan hukum kekekalan energi, energi potensial yang dihasilkan air dalam keadaan diam diubah menjadi energi kinetik, sehingga diperoleh kesamaan (gesekan antara air dengan galon diabaikan)

$$
m g h=\frac{1}{2} m v^{2}
$$

Dengan menyederhanakan persamaan 5 diperoleh rumus untuk kecepatan $v$ yaitu,

$$
v=\sqrt{2 g h}
$$

Jadi kecepatan air yang keluar dari keran dipengaruhi oleh ketinggian air (Tipler, 1998) dalam [8]. Sebuah galon diisi dengan air sampai ketinggian tertentu. Kemudian membuka keran galon tersebut. Berdasarkan Hukum Toricelli, jika diameter lubang kebocoran pada dinding wadah sangat kecil dibandingkan diameter wadah, kelajuan air yang keluar dari lubang sama dengan kelajuan yang diperoleh jika air tersebut jatuh bebas dari ketinggian $\mathrm{h}$ (Safitri, Islamiani, 2015) dalam [9]. 


\section{PBL (Problem Based Learning)}

Model pembelajaran berbasis masalah merupakan suatu model pembelajaran yang menggunakan masalah dunia nyata. Masalah tersebut digunakan sebagai suatu konteks bagi siswa untuk mempelajari cara berpikir kritis dan keterampilan pemecahan masalah, serta untuk memperoleh pengetahuan dan konsep yang esensial dari materi pelajaran (Kharida; Rusilowati; dan Pratiknyo, 2009) dalam [10]. Model Problem Based Learning atau dikenal dengan istilah model berbasis masalah sebagai salah satu model pembelajaran yang diterapkan dalam kurikulum 2013. Margetson (dalam Rusman, 2011) dan dikutip kembali dalam [11] menyebutkan bahwa Problem Based Learning sebagai model pembelajaran yang dapat membantu siswa untuk meningkatkan perkembangan keterampilan belajar sepanjang hayat dalam pola pikir yang terbuka, reflektif, kritis, dan belajar aktif, serta memfasilitasi keberhasilan memecahkan masalah, komunikasi, kerja kelompok, dan keterampilan interpersonal dengan lebih baik dibanding model lain.

Ibrahim dan Nur (2005) dalam [11] menyebutkan tujuan model berbasis masalah (Problem Based Learning) adalah sebagai berikut: (1) keterampilan berpikir dan keterampilan memecahkan masalah, (2) pemodelan peranan orang dewasa, dan (3) belajar pengarahan sendiri. Berdasarkan tujuan model pembelajaran tersebut bahwa model Problem Based Learning menitikberatkan pada pengembangan kemampuan tingkat berpikir tinggi dengan bantuan seorang guru sebagai fasilitator sehingga siswa dapat menentukan sendiri apa yang harus dipelajari, dan dari mana informasi tersebut diperoleh.

Ibrahim dan Nur (2005) dalam [11] menyebutkan bahwa pembelajaran berbasis masalah memiliki karakteristik sebagai berikut: (1) pengajuan masalah atau pertanyaan secara sosial penting dan secara pribadi bermakna untuk siswa karena sesuai dengan kehidupan nyata autentik, menghindari jawaban sederhana dan memungkinkan adanya berbagai macam solusi untuk situasi tersebut; (2) berfokus pada keterkaitan antara berbagai disiplin ilmu; (3) penyelidikan autentik dimana siswa menganalisis dan mendefinisikan masalah, mengembangkan hipotesis dan membuat ramalan, mengumpulkan dan menganalisis informasi, melakukan eksperimen (jika diperlukan), membuat inferensi dan merumuskan kesimpulan; dan (4) menghasilkan produk atau karya dan memamerkannya.

Guru atau pengajar akan dapat melakasanakan proses Pembelajaran Berbasis Masalah jika seluruh perangkat pembelajaran (masalah, formulir pelengkap, dan lain lain) sudah siap. Siswa juga harus sudah memahami prosesnya, dan telah membentuk kelompok-kelompok kecil. Sintaks dalam PBL secara umum adalah sebagai berikut: 1 . Mengorientasikan siswa pada masalah 2. Mengorganisasikan siswa untuk belajar 3. Membantu penyelidikan mandiri dan kelompok 4. Mengembagkan dan menyajikan hasil karya serta memamerkannya 5. Menganalisis dan mengevalusi proses pemecahan masalah (Shofiyah, Noly, Wulandari,dkk, 2018) dalam [12]

Pendidikan Karakter

Mengingat kembali bahwa kurikulum 2013 merupakan kurikulum yang dikembangkan berbasis kompetensi. Perbedaan Kurikulum 2013 dengan kurikulum sebelumnya terlihat dari adanya penambahan kompetensi sikap spiritual dan sikap sosial, selain kompetensi keterampilan dan pengetahuan. Keempat kompetensi dalam Kurikulum 2013 dikembangkan baik dalam indikator, materi, maupun evaluasi pembelajaran. Kurikulum 2013 lebih menekankan pada pencapaian kompetensi sikap spiritual, sosial, keterampilan, dan pengetahuan secara holistik. Hal tersebut mengingat tujuan Kurikulum 2013 berkaitan dengan terciptanya warga negara yang berkarakter. Kompetensi sikap berkaitan dengan pendidikan karakter. Pendidikan karakter dianggap sebagai usaha 
untuk menanamkan kebiasaan-kebiasaan baik sehingga siswa bersikap dan bertindak berdasarkan nila-inilai yang telah menjadi kepribadiannya. Penanaman nilai karakter harus secara wajib dimuat dalam buku teks yang digunakan oleh guru dan siswa, salah satunya.

Cubukcu (2012: 1527) dalam [13] mendefinisikan pendidikan karakter sebagai cara bagaimana mengajarkan siswa untuk memutuskan dengan baik dan bagaimana berperilaku yang sesuai. Lebih lanjut disebutkan bahwa, orang yang rendah hati, jujur, baik, setia, sabar dan bertanggung jawab diklasifikasikan sebagai orang-orang dengan karakter yang baik oleh orang lain. Pendapat ini dapat dimaknai bahwa karakter yang baik dapat ditanamkan kepada tiap siswa melalui pendidikan karakter. Hal tersebut sejalan dengan Lickona (2013: 82) dalam [13] yang menyatakan bahwa karakter yang baik terdiri dari mengetahui hal yang baik, menginginkan hal yang baik, dan melakukan hal yang baik (kebiasaan dalam cara berpikir, kebiasaan dalam hati, dan kebiasaan dalam tindakan). Berdasarkan pendapat tersebut, karakter yang baik harus diajarkan melalui pengetahuan moral terlebih dahulu, lalu siswa diajarkan untuk merasakan suatu moral, kemudian siswa akan melakukan tindakan mana yang dipilih setelah dipikirkan dengan matang.

Pendidikan karakter di Indonesia menjadi program yang memiliki tujuan dan fungsi yang terarah. Kemdiknas (2011: 7) dalam Panduan Pelaksanaan Pendidikan Karakter dan dikutip kembali oleh [13] menyebutkan bahwa pendidikan karakter bertujuan mengembangkan nilai-nilai yang membentuk karakter bangsa yaitu Pancasila, meliputi: 1) mengembangkan potensi peserta didik agar menjadi manusia berhati baik, berpikiran baik, dan berperilaku baik; 2) membangun bangsa yang berkarakter Pancasila; 3) mengembangkan potensi warganegara agar memiliki sikap percaya diri, bangga pada bangsa dan negaranya serta mencintai umat manusia. Sedangkan fungsi dari pendidikan karakter adalah: 1) membangun kehidupan kebangsaan yang multikultural; 2) membangun peradaban bangsa yang cerdas, berbudaya luhur, dan mampu berkontribusi terhadap pengembangan kehidupan umat manusia; mengembangkan potensi dasar agar berhati baik, berpikiran baik, dan berperilaku baik serta keteladanan baik; 3) membangun sikap warganegara yang cinta damai, kreatif, mandiri, dan mampu hidup berdampingan dengan bangsa lain dalam suatu harmoni [14].

Afektif

Ranah afektif mencakup penilaian watak perilaku seperti sikap, minat, konsep diri, nilai, dan moral. (Andersen, 1981) dalam [15] Kemampuan afektif berhubungan erat dengan minat dan sikap yang dapat berbentuk tanggung jawab, kerjasama, disiplin, komitmen, percaya diri, jujur, menghargai pendapat orang lain, dan kemampuan mengendalikan diri. Popham (1995) dalam Djemari Mardapi (2004) dan dikutip kembali oleh [15] menambahkan ranah afektif dapat menentukan keberhasilan belajar seseorang. Sehingga satuan pendidikan perlu membuat program penilaian yang mengoptimalkan ranah afektif. Penilaian tersebut memperhatikan sikap, minat, konsep diri, nilai, dan moral peserta didik saat pembelajaran.

Haryadi \& Aripin (2015, p. 41) dalam [16] menjelaskan bahwa afektif memiliki cakupan yang berbeda dengan kognitif, afektif lebih berhubungan dengan psikis, jiwa dan rasa. Dijelaskan lebih lanjut bahwa pada afektif meliputi sikap yang ditunjukkan. Afektif juga dapat di artikan sebagai proses yang menekankan nada perasaan, emosi, atau tingkat penerimaan atau penolakan. Tujuan afektif bervariasi dari perhatian sederhana pada fenomena terpilih hingga kualitas karakter dan hati nurani yang kompleks namun konsisten secara internal (Krathwohl et al., 1973, p. 7) dalam [16].

Analisis Produk dalam Mengembangkan Media Pembelajaran 
Pembuatan miniatur tersebut berlandaskan pada materi tekanan hidrostatis. Tekanan Hidrostatis merupakan tekanan yang diberikan zat cair ke semua arah pada suatu benda akibat adanya gaya gravitasi. Tekanan Hidrostatis akan meningkat seiring dengan bertambahnya kedalaman yang diukur dari permukaan zat cair. Hal yang perlu diperhatikan dalam tekanan hidrostatis adalah massa jenis suatu zat cair yang mengenai suatu benda tersebut. Dari percobaan yang dilakukan terdapat 4 data dengan ketinggian air di dalamnya yang berbeda. Berikut penjelasan terkait percobaan pada miniatur pancuran untuk mengembangkan pembelajaran integrasi dengan memadukan atau mendemonstrasikan ranah kognitif dengan ranah afektif.

Hasil atau Data yang diperoleh dalam percobaan

\begin{tabular}{|l|l|l|}
\hline No. & Kedalaman & Jarak Pancaran Air \\
\hline 1. & $20 \mathrm{~cm}$ & $15 \mathrm{~cm}$ \\
\hline 2. & $15 \mathrm{~cm}$ & $18 \mathrm{~cm}$ \\
\hline 3. & $10 \mathrm{~cm}$ & $25 \mathrm{~cm}$ \\
\hline 4. & $5 \mathrm{~cm}$ & $28 \mathrm{~cm}$ \\
\hline
\end{tabular}

Tabel 1. Hasil Percobaan dalam Demonstrasi Produk

Demonstrasi Produk

Pada percobaan tersebut, konsep fisika yang dapat dibahas secara mendasar yaitu materi tentang Tekanan Hidrostatis dan Hukum Torricelli. Dalam tekanan hidrostatis disebutkan bahwa besarnya gaya tekan zat cair yang dialami oleh alas bejana tiap satuan luas dan tekanan total di tempat atau titik yang berada pada kedalaman $\mathrm{h}$, sehingga dapat dipahami bahwa tekanan hidrostatis dianggap mengalami tingkat tekanan yang besar maka ketinggian fluida atau zat cair tinggi atau semakin tinggi tekanan yang diperoleh maka ketinggian zat cair atau fluida tersebut tinggi dan begitu juga sebaliknya. Penerapan akan tekanan hidrostatis dengan nilai tekanan tinggi maupun kecil dapat diketahui apabila bejana atau wadah mengalami kebocoran sehingga dapat berlaku hukum Torricelli Menurut Hukum Torricelli, semakin lama kecepatan air keluar semakin kecil sesuai dengan ketinggian cairan yang semakin menurun (Halliday, Resnick, \& Walker, 2005) dalam [8]. hal ini berkaitan dengan kecepatan air mengalir melalui lubang dalam tangki atau wadah.

Berikut ini merupakan hasil percobaan dalam mendemonstrasikan produk yang menerapkan materi tekanan hidrostatis dan hukum Torricelli.

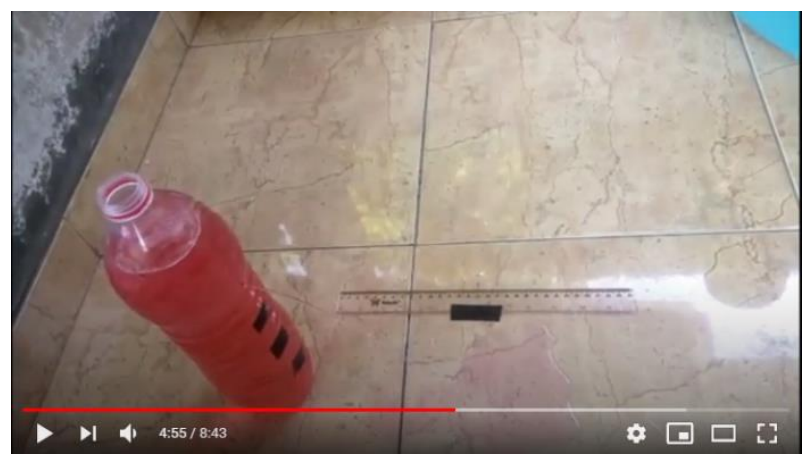

Gambar 2. Hasil percobaan pertama dalam demonstrasi produk 
Dari percobaan pertama dalam mengembangkan media pembelajaran menunjukkan pancuran air sejarak $15 \mathrm{~cm}$. Dalam percobaan pertama, ketinggian antara lubang hingga dasar wadah (botong) yaitu $20 \mathrm{~cm}$. Ketika lubang pertama dibuka, maka penerapan hukum Torricelli berlaku. Dalam peristiwa bocornya air tersebut menunjukkan semakin lama air mengalir dalam lubang, maka ketinggian zat cair yang mengalami tekanan (ketinggian zat cair dari permukaan hingga lubang) akan semakin rendah atau nilainya lebih kecil. Begitu pula yang dialami oleh percobaan kedua dan seterusnya. Perhatikan beberapa gambar dari hasil percobaan dalam demonstrasi produk.

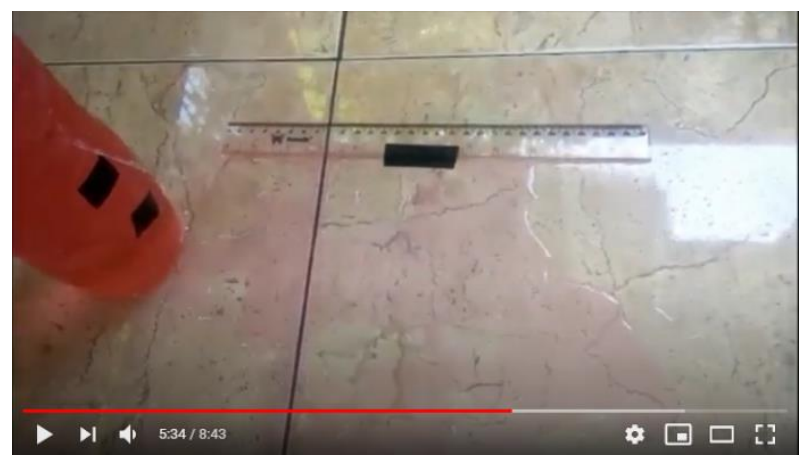

Gambar 3. Hasil percobaan menunjukkan air yang keluar berada pada titik $18 \mathrm{~cm}$ dengan ketinggian (dari dasar ke lubang kedua) $15 \mathrm{~cm}$.

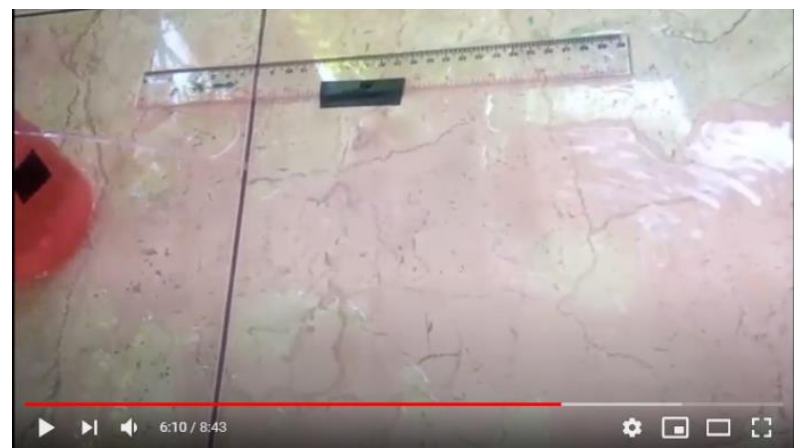

Gambar 4. Hasil percobaan menunjukkan air yang keluar berada pada titik $25 \mathrm{~cm}$ dengan ketinggian (dari dasar ke lubang kedua) $10 \mathrm{~cm}$.

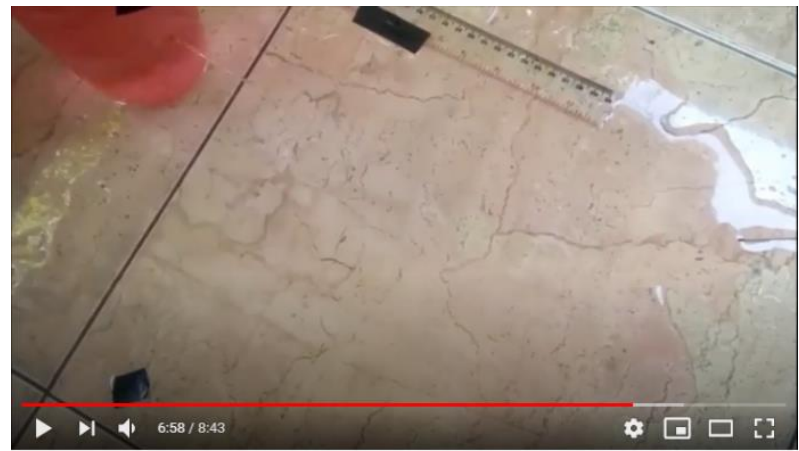

Gambar 5. Hasil percobaan menunjukkan air yang keluar berada pada titik $28 \mathrm{~cm}$ dengan ketinggian (dari dasar ke lubang kedua) $5 \mathrm{~cm}$.

Dari serangkaian percobaan dapat diketahui dan diambil pembelajaran tentang IPA khususnya fisika bahwasanya semakin tinggi kedalaman air pada tekanan hidrostatis (kedalaman dari permukaan air hingga lubang), maka jarak (wadah ke titik jatuhnya air) keluarnya air hingga menuju permukaan tanah lebih panjang. Apabila ditinjau dari ketinggian dasar wadah terhadap tiap lubang, apabila jaraknya pendek, maka jaraknya 
keluar air menyentuh permukaan tanah lebih panjang. Dari percobaan ini dapat dipahami akan konsep tekanan hidrostatis dan hukum Torricelli secara mendasar dan penerapan secara sederhana dalam kehidupan sehari-hari

Hasil analisis

Tekanan merupakan materi pembelajaran IPA cabang ilmu fisika yang membahas daya tekan pada suatu zat atau benda yang sering ditemukan dalam kehidupan seharihari dan pengembangan ilmu terapannya yang sering dikenal dalam kehidupan seharihari. Dalam mengkaji suatu pengetahuan akan tekanan agar dapat dipahami dan direalisasikan dalam kehidupan masyarakat serta keseharian atau aktivitas kesehariannya diperlukan pemahaman akan konsep tekanan itu sendiri. Dengan itu perlu dikuatkan akan materi tekanan bagi siswa agar dapat mencapai pengetahuan yang terintegrasi dan terealisasi dengan kehidupan sebagaimana yang menjadi tujuan pembelajaran yang tersusun dan tercantum dalam kurikulum terbaru yaitu kurikulum 2013.

Membahas masalah akan pembelajaran yang akan disampaikan dan diajarkan kepada peserta didik (siswa) menjadi sebuah kewajiban dan tantang bagi guru atau tenaga pendidik untuk melaksanakan kewajibannya. Terlebih lagi dengan adanya kebijakan yaitu peralihan dan perubahan kurikulum dari kompetensi tingkat satuan pendidikan atau yang dikenal dengan KTSP hingga menjadi kurikulum 2013 dan telah berlangsung dan terlaksana hingga saat ini. Untuk itu pembelajaran yang bersifat kompetensi dan integratif perlu berkembang secara signifikan terhadap perkembangan zaman pula demi tercapainya tujuan pendidikan yang dilakukan oleh guru. Oleh karena itu, penulis berinisiatif mengembangkan sebuah tulisan utnuk tercapainya pembelajaran yang sesuai dengan kurikulum 2013 pada salah satu materi yaitu Tekanan dengan melaksanakan pembelajaran yang bersifat integratif yang tidak hanya mengembangkan kompetensi pada ranah kognitif dan psikomotorik saja, namun juga mengembangkan kompetensi pada ranah afektif, yaitu mengembangkan sikap spiritual dan sosial sebagaimana yang tercantum dalam kompetensi inti (KI) dalam kurikulum 2013. Mengembangkan ranah afektif yang direncanakan dan dikembangkan penulis pada materi tekanan hidrostatis melalui media demonstrasi berupa miniatur pancuran.

Dari percobaan pertama hingga keempat menunjukkan pembelajaran kepada peserta didik terkait materi atau pengetahuan (kognitif) peserta didik yaitu mengajarkan materi fisika dengan dua persamaan sekaligus yaitu tekanan hidrostatis dan hukum Torricelli. Mengingat kembali akan ketentuan dalam kurikulum bahwasanya pembelajaran menuntut sistem pengembangan kompetensi, seperti kompetensi sikap spiritual, sosial, pengetahuan dan keterampilan. Penerapan akan pembelajaran IPA khususnya dalam materi fisika tekanan sikap afektif dapat dikembangkan dengan melalui keterkaitan materi dengan kehidupan sosial sehari-hari. Ketika mendemonstrasikan produk dan menjelaskan materi, di situlah diselingi pula pembelajaran akan sikap, dimana dalam menyampaikan "semakin tinggi kedalaman air pada tekanan hidrostatis (kedalaman dari permukaan air hingga lubang), maka jarak (wadah ke titik jatuhnya air) keluarnya air hingga menuju permukaan tanah lebih panjang" disampaikan pesan pula bahwa "dalam keadaan terkekang dengan adanya tekanan hidup berupa tekanan batin, maka keadaan jiwa dan hati nurani harus menerima dengan lapang dada dan terapkan sikap sabar dan bersyukur dalam menghadapi keadaan tekanan batin tersebut".

Proses pembelajaran yang akan dilaksanakan dan direncanakan memenuhi sintaks sebagai berikut: 1. Mengorientasikan siswa pada masalah 2. Mengorganisasikan siswa untuk belajar 3. Membantu penyelidikan mandiri dan kelompok 4. Mengembagkan dan menyajikan hasil karya serta memamerkannya 5 . Menganalisis dan mengevalusi proses 
pemecahan masalah (Shofiyah, Noly, Wulandari,dkk, 2018) dalam [12]. Pada proses pembelajaran, seperti biasa dilakukan dengan sebagaimana pembelajaran pada umunya yaitu terdiri dari kegiatan pendahuluan, inti dan penutup. Hal yang membedakan dengan proses pembelajaran dengan model pembelajaran tertentu khususnya pada model pembelajaran PBL (Problem Based Learning) yaitu pada proses atau kegiatan inti.

Kegiatan inti pada sintaks atau proses kegiatan pertama "Mengorientasikan siswa pada masalah". Guru memulai pembelajaran dengan menyampaikan materi tekanan yang sering dimanfaatkan dalam kehidupan sehari-hari, yaitu khususnya pada materi tentang Hukum Torricelli yaitu pancuran. Guru menyampaikan secara singkat video terkait proses keluarnya air melalui lubang dalam sebuah pancuran sederhana. Dilanjutkan dengan menyampaikan penerapan materi yang didemonstrasikan dengan menggunakan media miniatur pancuran dengan media botol bekas dengan lubang atau titik bocor dengan ketinggian tertentu. Hasil demonstrasi ditunjukkan pada gambar 2 hingga gambar 5 .

Pada proses atau kegiatan kedua "Mengorganisasikan siswa untuk belajar". Dalam tahap ini guru membagi jumlah siswa di kelas dengan beberapa kelompok kecil dengan beranggotakan 4-5 anak. Dalam pembagian kelompok tersebut guru menyampaikan tujuan dilasanakannya pembagian kelompok dengan mengajak siswa untuk menganalisis percobaan yang diilustrasikan pertama oleh guru dan memberikan kesempatan diskusi secara berkelompok untuk memahami materi. Guru memberikan alat dan bahan secara sederhana untuk tiap kelompok untuk merangkai produk yang diilustrasikan guru. Guru menyampaikan tugas dengan "analisis tekanan pada pancuran miniatur, air yang keluar dalam lubang atau titik bocor yang berbeda menghasilkan titik jatuh air yang berbeda pula. Mengapa demikian? Bagaimana hubungan miniatur tersebut dengan materi tekanan?"

Dalam proses ketiga "Membantu penyelidikan mandiri dan kelompok". Kegiatan ini dilakukan oleh siswa dan guru mengamati proses dan keaktifan kelompok beserta anggotanya. Dengan proses ini guru memberikan kebebasan kepada siswa untuk memanfaatkan referensi yang telah disediakan yaitu buku, diskusi materi dan bertukar pendapat, serta lain sebagainya.

Proses pembelajaran yang keempat "Mengembagkan dan menyajikan hasil karya serta memamerkannya". Dalam kegiatan ini tiap kelompok melakukan presentasi atau mendemonstrasikan hasil karya kelompok dan menyampaikan materi atau rumusan masalah yang disampaikan guru. Sebelumnya, guru menetukan kelompok mana saja yang mendemostrasikan produk, menyampaikan materi, menyampaikan pemecahan masalah dari rumusan masalah yang diberikan dan contoh penerapan lain dalam kehidupan sehari-hari dalam topik materi tekanan khususnya Hidrostatis dan Hukum Torricelli. Kemudian guru menyampaikan untuk mengamati dan menyimak penjelasan dari tiap kelompok dan mencatat serta melakukan pertanyaan atau diskusi secara bebas kepada siswa dalam proses pembelajaran. Siswa dalam kegiatan ini dituntut untuk memberikan pertanyaan, sanggahan atau feedback untuk memecahkan permasalahan yang disampaikan oleh guru dalam kegiatan awal.

Kegiatan inti yang kelima "Menganalisis dan mengevalusi proses pemecahan masalah". Kegiatan ini, guru memberikan evaluasi terkait proses pembelajaran dan hasil diskusi serta meluruskan materi tekanan yang dimungkinkan ada kekliruan dalam diskusi. Dilajutkan dengan proses tanya jawab antara siswa dengan guru serta berlanjut pada kegiatan penutup.

Proses pembelajaran dalam kajian religius tersebut ketika materi tentang tekanan disampaikan, sekaligus mengajarkan siswa atau peserta didik untuk belajar melapangkan 
hati, bersabar dan jangan berkeluh kesah, yang mana ketiganya bersumber dari terbentuknya sikap atau akhlak dari seseorang [17]. Ketiga nilai sikap religius tersebut merupakan tujuan yang dapat diterapkan dalam konsep pendidikan akhlak manusia yang terkandung dalam QS. Al-Ma'arij (70): 19-21.

Artinya: (19) Sungguh, manusia diciptakan bersifat suka mengeluh. (20) Apabila dia ditimpa kesusahan dia berkeluh kesah, (21) dan apabila mendapat kebaikan (harta) dia jadi kikir (QS. Al-Ma'arij (70): 19-21.)

Dalam kajian lengkapnya yaitu kandungan ayat dalam QS. QS. Al-Ma'arij (70): 19-35 tentang pendidikan akhlak yang dapat menuntun ke jalan yang benar dan menjadikan kehidupannya tenang serta nyaman [17].

Artinya: (19) Sungguh, manusia diciptakan bersifat suka mengeluh. (20) Apabila dia ditimpa kesusahan dia berkeluh kesah, (21) dan apabila mendapat kebaikan (harta) dia jadi kikir, (22) kecuali orang-orang yang melakukan shalat, (23) mereka yang tetap setia melaksanakan shalatnya, (24) dan orang-orang yang dalam hartanya disiapkan bagian tertentu, (25) bagi orang (miskin) yang meminta dan yang tidak meminta, (26) dan orang-orang yang memercayai hari pembalasan, (27) dan orang-orang yang takut terhadap azab Tuhannya, (28) sesungguhnya terhadap azab Tuhan mereka, tidak ada seseorang yang merasa aman (dari kedatangannya), (29) dan orang-orang yang memelihara kemaluannya, (30) kecuali terhadap istri-istri mereka atau hamba sahaya yang mereka miliki maka sesungguhnya mereka tidak tercela. (31) Maka barangsiapa mencari di luar itu ( seperti zina, homoseks, dan lesbian), mereka itulah orang-orang yang melampaui batas. (32) Dan orang-orang yang memelihara amanat dan janjinya, (33) dan orang-orang yang berpegang teguh pada kesaksiannya, (34) dan orang-orang yang memelihara shalatnya. (35) Mereka itu dimuliakan di dalam surga. (QS. QS. AIMa'arij (70): 19-35).

Dalam menyampaikan materi tentang tekanan dapat juga diselingi dengan kajian tentang belajar melapangkan hati, bersabar dan jangan berkeluh kesah agar dapat terciptanya pembelajaran yang sesuai dengan ketentuan kurikulum 2013. Kajian afektif dapat ditambahkan dengan menjelaskan konsep jangan keluh kesah dengan menggantikan sikap sabar karena setiap ada ujian kesulitan (berupa tekanan batin dalam hidup atau permasalahan pribadi atau sosial) pasti ada jalan keluarnya atau solusi, sebagaimana yang dijelaskan dalam firman Allah SWT. (QS. Asy-Syarh (94): 5-6) [17].

Artinya: (5) Maka sesungguhnya bersama kesulitan ada kemudahan, (6) sesungguhnya bersama kesulitan ada kemudahan, (QS. Asy-Syarh (94): 5-6)

Dari penyampaian materi tekanan hidrostatis yang diikuti pula dengan hukum Torricelli, keterkaitan atau keterpaduan akan IPA dapat disampaikan pula, seperti hadirnya benda alam disekitar dan pemanfaatannya yaitu air, dimana sangat terpadu dengan materi tekanan hidrostatis. Dalam bagian pembelajaran IPA dengan pengetahuan atau keterpaduan pada ranah afektif dapat disampaikan peran dan keberadaan air dalam kehidupan. Air merupakan sumber daya yang sangat besar dan bisa didapati di berbagai tempat di belahan bumi. Keberadaannya sangat diperhatikan oleh manusia karena besarnya kemanfaatan air bagi kehidupan. Terlebih, air merupakan pemberian dari Allah bagi makhluk-Nya di bumi. Pemberian ini dapat dimanfaatkanoleh seluruh makhluk-Nya, baik manusia, hewan, maupun tumbuhan (QS An Nahl 16:10).

Artinya: (10) Dialah yang telah menurunkan air (hujan) dari langit untuk kamu, sebagiannya menjadi minuman dan sebagiannya (menyuburkan) tumbuhan, padanya kamu menggembalakan ternakmu. (QS An Nahl 16:10). 
Begitu pentingnya air bagi kehidupan, hingga Allah menyebutkan air dan yang berhubungan dengannya secara berulang-ulang dalam Al Qur'an. Kata air (ma') disebut 63 kali, sungai dan sungai-sungai (nahr dan anhar) disebut 54 kali, dan air minum (syariba) disebut 39 kali (Naff, 2009:40) dalam [18]. Dalam pembahasan air ini, dapat pula disinggung materi tentang siklus hidrologi sebagai pengetahuan awal dan dasar untuk peserta didik dalam memahami materi dan meresapi serta mengabstrakkan atau menerapkan dalam kehidupan sehari-hari. Siklus air (hidrologi) adalah perjalanan air di dalam alam, ia bergerak dari satu fase melalui atmosfer, turun dan masuk ke dalam tanah, ke lautan, dan kembali lagi ke atmosfer (Brutsaert, 2005: 3) dalam [18]. Seluruh perjalanan air dalam siklus hidrologi terjadi dengan mekanisme tertentu yang telah diatur oleh Allah sebagaimana firman-Nya dalam QS. An Nur 24 : 43.

Artinya: (43) Tidakkah engkau melihat bahwa Allah menjadikan awan bergerak perlahan, kemudian mengumpulkannya, lalu dia menjadikan bertumpuk-tumpuk, lalu engkau lihat hujan keluar dari celah-celahnya, dan Dia (juga) menurunkan (butiran-butiran) es dari langit, (yaitu) dari (gumpalan-gumpalan awan seperti) gunung-gunung maka ditimpakan-Nya (butiran-butiran es) itu kepada siapa yang Dia kehendaki dan dihindarkan-Nya dari siapa yang Dia kehendaki. Kilauan kilatnya hampir-hampir menghilangkan penglihatan. (QS. An Nur 24 : 43.)

Allah mengarak awan dengan kekuasaan-Nya, kemudian mengumpulkannya setelah berserakan di sana-sini. Lalu Allah jadikan saling bertumpang tindih yang satu di atas yang lain. Maka hujan keluar dari celah-celahnya. Dan Allah juga menurunkan butiran-butiran es dari langit, yaitu dari gumpalan-gumpalan awan seperti gununggunung. Maka ditimpakanNya dengan menurunkan dua jenis hujan dari langit (hujan biasa dan hujan es) kepada yang dikehendaki-Nya sebagai rahmat dari-Nya (Al-Sheikh, 2004: 71) dalam [18].

Terkait peran, kelestarian air juga diperlukan dan dibutuhkan dalam pembelajaran untuk peserta didik, dimana hal tersebut dapat menjadikan pembelajaran IPA yang terpadu, baik terpadu dengan cabang ilmu selain fisika (seperti biologi atau kimia) maupun dengan pembelajaran ranah afektif. Dalam melestarikan suatu lingkungan atau objek di alam, pasti tidak luput dari usaha dan tindakan dari manusia itu sendiri. Terwujudnya kelestarian air tidak terlepas dari usaha-usaha konservasi air itu sendiri. Atau dengan kata lain, konservasi air merupakan upaya yang diperlukan untuk melestarikan sumber daya air. Menurut Subagyono (2007) dalam (Darmawan, 2008) dan dikutip kembali oleh [19], strategi konservasi air diarahkan untuk meningkatkan cadangan air pada wilayah perakaran tanaman dengan upaya-upaya pengendalian aliran permukaan, peningkatan infiltrasi, pengurangan evaporasi, dan introduksi tanaman yang hemat air. Kegiatan penanaman pohon oleh masyarakat dapat dikatakan sebagai upaya konservasi air karena di dalamnya terdapat tindakan untuk mengendalikan aliran permukaan dan meningkatkan infiltrasi air hujan. Dengan adanya pohon-pohon di atas permukaan tanah, diharapkan akan tersimpan "persediaan air yang cukup banyak di dalam tanah" sehingga masyarakat tidak akan kekurangan air. Selain itu juga manfaat penanaman pohon untuk menghindar kekhawatiran akan bahaya perubahan lingkungan menumbuhkan kesadaran bagi masyarakat. Hal ini dimaksudkan untuk meningkatkan kemampuan tanah dalam menyerap air tanah. Penggunaan lahan akan mempengaruhi kuantitas dan kualitas ketersediaan air tanah, karena vegetasi memiliki peran yang sangat penting dalam mengendalikan runoff dan meningkatkan kemampuan infiltrasi air (Wang et al, 2014; Targa dan Batista, 2015) dalam (Lestari, 2008) dan dikutip kembali oleh [19]. Adanya bahaya banjir yang dapat terjadi pada saat musim penghujan, telah memberikan kesadaran bagi masyarakat akan pentingnya keberadaan pohon-pohon besar di lingkungan mereka. Terjaganya lingkungan dari kerusakan diharapkan dapat mencegah bahaya banjir seperti yang pernah terjadi di desa Ngalam Baru pada tahun 
2004. Oleh karena itu mereka pun berusaha memelihara tanaman yang tumbuh di kanan kiri sungai yang merupakan tempat sebagian anggota masyarakat melakukan aktivitas mencuci dan mandi. Adanya air dan dampak tersebut juga dipengaruhi oleh keadaan atau kondisi hidrologinya pula [19].

\section{KESIMPULAN}

Dalam pembelajaran IPA untuk memenuhi ketentuan dalam kurikulum 2013 bahwasanya pembelajaran dilakukan dengan mengajarkan materi pada peserta didik untuk mengembangkan kompetensi yaitu kompetensi sikap spiritual, sosial, pengetahuan dan keterampilan. Untuk melaksanakan pembelajaran tersebut pembelajaran yang diterapkan yaitu mengajarkan materi tekanan hidrostatis. Pembelajaran dengan materi tersebut diintegrasikan dalam ranah afektif yaitu spiritual dan sosial serta keterpaduan antara cabang ilmu lainnya dengan menyertakan firman Allah SWT. agar dapat diterapkan dalam kehidupan sehari-hari, baik dalam lingkungan keluarga maupun lingkungan sosial bermasyarakat.

\section{DAFTAR PUSTAKA}

[1] S. I. Zulfa, A. Nikmah, and E. K. Nisak, "Analisis Penguasaan Konsep pada Tekanan Hidrostatis dan Hukum Pascal Mahasiswa Pendidikan Fisika," p. 6, 2019.

[2] I. Rahmawati, A. Hidayat, and S. Rahayu, "Peguasaan Konsep IPA Siswa SMP pada Materi Tekanan pada Zat Cair dan Aplikasinya," vol. 4, no. 3, p. 11, Sep. 2016.

[3] I. Rahmawati, A. Hidayat, and S. Rahayu, "Peguasaan Konsep IPA Siswa SMP pada Materi Tekanan pada Zat Cair dan Aplikasinya," p. 11, Sep. 2016.

[4] S. W. Pujaningtyas, B. Kartakusumah, and Z. K. Lathifah, "Penerapan Model Experiential Learning Pada Sekolah Alam Untuk Menciptakan Pembelajaran Yang Menyenangkan," TADBIR MUWAHHID, vol. 3, no. 1, p. 40, May 2019, doi: $10.30997 / \mathrm{jtm} . v 3 i 1.1653$.

[5] I. L. Mariatun and Indriani, Dian Eka, "Penguatan Pendidikan Karakter Berbasis Pancasila melalui Kurikulum K13 di Sekolah Dasar," p. 8.

[6] I. Islahudin, F. Riadi, R. Rosdaniah, and Y. Y. Yustina Yuyun, "Rancang Bangun Sensor Tekanan Berbasis Koil Datar Untuk Mengukur Tekanan Hidrostatis Air Bendungan Rawan Banjir di Wilayah Lombok Nusa Tenggara Barat," Orbita J. Kaji. Inov. Dan Apl. Pendidik. Fis., vol. 5, no. 1, p. 1, Jun. 2019, doi: 10.31764/orbita.v5i1.893.

[7] I. Safitri, "Pembelajaran Tekanan Hidrostatik, Kapilaritas, Dan Debit Zat Cair Melalui Power Point, Video, Dan Modul Eksperimen," vol. 2, no. 2, p. 6, 2015.

[8] M. M. Chusni, K. Nisa, and M. Haidir, "Penerapan Diferensial untuk Mengukur Laju Perubahan Volume Air Galon," p. 6.

[9] I. Safitri, "Pembelajaran Tekanan Hidrostatik, Kapilaritas, dan Debit Zat Cair Melalui Power Point, Video, Dan Modul Eksperimen," vol. 2, no. 2, p. 6, 2015. 
[10] N. Nurdyansyah and F. Amalia, "Model Pembelajaran Berbasis Masalah Pada Pelajaran IPA Materi Komponen Ekosistem," p. 8.

[11] Y. D. Haryanti, "Model Problem Based Learning Membangun Kemampuan Berpikir Kritis Siswa Sekolah Dasar," J. Cakrawala Pendas, vol. 3, no. 2, Jul. 2017, doi: $10.31949 /$ jcp.v3i2.596.

[12] N. Shofiyah and F. E. Wulandari, "Model Problem Based Learning (PBL) dalam Melatih Scientific Reasoning Siswa," J. Penelit. Pendidik. IPA, vol. 3, no. 1, p. 33, Aug. 2018, doi: 10.26740/jppipa.v3n1.p33-38.

[13] Y. K. Adi, "Analisis Muatan Pendidikan Karakter Dalam Buku Teks Kurikulum 2013 Kelas III SD Semester 1," Profesi Pendidik. Dasar, vol. 1, no. 1, p. 23, Jan. 2018, doi: 10.23917/ppd.v1i1.3754.

[14] D. Febrianshari and D. W. Ekowati, "Analisis Nilai-Nilai Pendidikan Karakter dalam Pembuatan Dompet Punch Zaman Now," J. Pemikir. Dan Pengemb. Sekol. Dasar JP2SD, vol. 6 , no. 1 , p. 88 , Jun. 2018, doi: 10.22219/jp2sd.v6i1.5907.

[15] M. Saftari and N. Fajriah, "Penilaian Ranah Afektif dalam Bentuk Penilaian Skala Sikap Untuk Menilai Hasil Belajar," Edutainment J. Ilmu Pendidik. Dan Kependidikan, vol. 7, no. 1, pp. 71-81, Aug. 2019, doi: 10.35438/e.v7i1.164.

[16] A. Riscaputantri and S. Wening, "Pengembangan instrumen penilaian afektif siswa kelas IV sekolah dasar di Kabupaten Klaten," J. Penelit. Dan Eval. Pendidik., vol. 22, no. 2, pp. 231-242, Dec. 2018, doi: 10.21831/pep.v22i2.16885.

[17] L. E. Maimunah Ummu Sa'idah, "Konsep Pendidikan Akhlak dalam Al-Qur'an Surah Al-Ma'arij Ayat 19-35 (Kajian Tafsir Al-Maraghi)," Kuttab J. Ilm. Mhs., vol. 1, no. 1, p. 43, Jan. 2019, doi: 10.33477/kjim.v1i1.883.

[18] Z. Z. Nisa, "Konsep Pengelolaan Air dalam Islam," J. Penelit., vol. 14, no. 1, p. 77, Aug. 2017, doi: 10.28918/jupe.v14i1.815.

[19] A. R. B. Nugroho and I. P. Haty, "Perubahan Sistem Kelestarian Air Tanah di Cekungan Air Tanah Wates Akibat Pembangunan Bandara Internasional Temon Kabupaten Kulonprogo DIY," vol. 3, p. 13, 2015. 